\title{
SHOULD FL TEACHERS STOP YOUNG LEARNERS' INITIATIONS?
}

\author{
María Isabel Velasco Moreno, Grupo de Investig. HUM-887, Univ. \\ Córdoba $^{1}$ \\ Email: mvelasco@andaluciajunta.es
}

\begin{abstract}
Although most researchers and practitioners agree on the limitations teacherfronted classes put on the learners' contribution to classroom interaction, we coincide with those who believe that, in spite of this more rigid form of interaction, students are able to take the initiative. Given the relevance such initiatives may have, especially in FL classes, we still consider it necessary to examine them in detail.

Based on the standard model of discourse analysis (Sinclair and Coulthard, 1975; Tsui, 1994) we focused on how learners and teachers co-build the communicative discourse generated in class. This empirical study made on data obtained from 12 classes of English as a foreign language in Spanish Primary Schools aims to show how the teacher-fronted class is not an obstacle for students to make initiative turns. It provides a taxonomy of acts according to the illocutionary force that prompt them and a typology of 'incises' derived from them.
\end{abstract}

Keywords: Classroom interaction, learner initiation turns, learning opportunities, discourse analysis, FL classes

Titulo en español: ¿Deberían detenerse las iniciaciones de los niños en clase?

Resumen: Aunque la mayoría de investigadores y docentes coinciden en las limitaciones que las clases tradicionales presentan para la contribución del alumnado a la interacción verbal de clase, coincidimos con los que opinan que, a pesar de su rigidez, los estudiantes son capaces de tomar la iniciativa. Dada la importancia que tales iniciaciones pueden tener, especialmente en las clases de Lengua Extranjera, creemos que es preciso estudiarlas en profundidad.

Por ello, tomando como base el modelo tradicional de análisis del discurso (Sinclair and Coulthard, 1975; Tsui, 1994), nos hemos centrado en analizar de qué forma los aprendices junto con el docente generan el discurso comunicativo del aula. El estudio empírico, realizado con datos obtenidos de 12 clases de inglés como Lengua Extranjera en colegios españoles de Enseñanza Primaria, pretende mostrar cómo las clases tradicionales no suponen realmente un impedimento para que los discentes realicen turnos iniciadores. En este artículo, se proporciona una taxonomía de actos verbales de iniciación según la fuerza ilocutiva que los promueve así como una tipología de 'incisos' derivados de los mismos. Palabras clave: Interacción en clase, turnos iniciadores del alumnado, oportunidades de aprendizaje, análisis del discurso, clases de lengua extranjera.

Date of reception: 27 June 2013

Date of Acceptance: 3 September 2013 


\section{INTRODUCTION}

Foreign Language Education is one of the main concerns in our current society and great efforts have been made in order to improve FL classes. The last decades have witnessed an increase of educational studies following the aim of reaching faster and better results in foreign language learning but it is relatively easy to find that much research is focused on previous phases like lesson planning studies or post-classes investigations (Bailey, 1996) instead of focusing on the teaching-learning process. The first steps on Discourse Analysis (Sinclair and Coulthard, 1975) helped greatly to understand classes and many surveys have been conducted on classroom interaction (Allwright, 1983; Tsui, 1994; Johnson, 1995; Richards and Seedhouse 2005, Walsh, 2006; 2011, Velasco, 2012). Garton (2012) is right when stating that much previous research about classes has been made on teachers's talking, giving little relevance to students' actual talking.

Our attempt in this paper is to investigate classroom development from the students' point of view, paying special attention to the learners' participation, especially nowadays when practitioners and researchers claim that learning is considered to be more dependent on the initiative of the learner and the activity carried out than the transmission of simple inputs to the learner by a teacher or a textbook (Allwright, 2005; Goodwin, 2007; Van Lier, 2008). Allwright's proposal of considering the analysis of the learning opportunity with implications for planning is extremely important because the teaching standpoint is starting to be relegated to a second place. However, admitting to its existing, he suggests that better learning results could be obtained from the opportunities that arise during the classroom language learning period. Now more than ever much practitioners' research is needed with exploratory practice. Despite classroom interaction may seem to be unpredictable, we think that research into Foreign Language classes, especially focused on what learners say, could greatly help teachers to find better ways to improve L2 classes and help students to learn profitably.

Surprisingly, it is only in recent studies where we can find rising interest for this very important issue. Some researchers, like Waring (2009) or Garton (2012), refer to this type of contribution as 'learner initiatives', but we prefer the term given by Fagan (2012) 'learners' unexpected contribution', as it is certainly unexpected for teachers and the rest of class members what students can say when speaking spontaneously, that is, without being asked to do so. Certainly, definitions vary in the literature; for example, Jacknick (2009) refers to it as 'unsolicited learner participation' which is unexpected by the teacher. The impact this may have on the class development seems to be a major issue, according to this view. In Fagan's words (2012:109):

It has been found that teachers could encourage sequence continuation when a learner initiates a topic familiar to the teacher, or even abandon their lesson plan to pursue the initiation if the teacher deems it necessary as part of the learning process.

In spite of having investigated the same phenomena, they have come to different conclusions. For example, Jacknick (2009) studies the sequential environments in which 
learner-initiated participation can occur: (1) following a teacher's or (2) a learner's initiation, (3) in the mid of the teacher's turn or (4) while changing from one activity to another.

This way, Waring's (2011) strives for an understanding of the nature of learners' initiative, observing and giving examples of three types: (A) initiating a sequence, (B) volunteering response and $(\mathrm{C})$ exploiting assigned turns.

In addition, Fagan (2012), considering that learners' initiatives can occur either in teacher or learner-initiated sequences-of-talk, discerns two different types of teacher discursive practices in response to the learners' unexpected contribution: (1) glossing over the learners' contributions and (2) assuming the role of information provider. In contrast, Garton's states (2012:33) that “... learner initiative can occur at any point in an IRF sequence, and not only upon completion of it".

Two main requisites are included in her definition of learner initiative: the learner's turn is self-selected and it gains the main floor and is not just limited to a sub-floor. Instead of investigating the classroom context in which learner initiatives occur, she examines the number of occurring types, finding four different types: (1) confirmation checks; (2) clarification requests; (3) information requests and (4) hypothesis testing.

The relevance of all these studies is unquestionable, but we notice that all of them have been carried out in adult academic settings. We are conscious of the importance of exploring younger learners' participation in class to get a better knowledge of their contribution in order to improve their FL learning. Our research is focused on Spanish young learners' initiatives in the English class.

\section{OBJECTIVES}

Our main concern in this article is to investigate whether young FL learners produce initiations in FL teacher-fronted classes or not. Our second aim is to explore the origin of such initiation turns and finally, we are interested in knowing how they can affect the FL teaching-learning process. In short, we would like to answer the following questions:

a) Do Spanish children make initiations in Foreign Language classes?

b) Why do learners make initiations in FL classes?

c) How can learners' initiations affect classroom development?

\section{The study}

We have settled our research on six groups in different Andalusian schools. Twelve classes were surveyed and studied in detail and a total of 105 Spanish children (5 to 13 years old) learning English as a second language have participated.

Group 1, G2 and G6 belong to private schools, which means that $50.5 \%$ of the participants study at private schools and $49.5 \%$ of them are registered at public schools (G3, G4 and G5).

On table 1 it is shown the academic level as well as the number of students per group. 


\begin{tabular}{|l|l|l|}
\hline Group & Level/Age & Num. students \\
\hline G1 & Preschool $(5 / 6$ years old $)$ & 15 \\
\hline G2 & English Academy $(6 / 7$ years old $)$ & 10 \\
\hline G3 & Primary $3^{\text {rd }}(8$ years old $)$ & 22 \\
\hline G4 & Primary $6^{\text {th }}(12$ years old $)$ & 21 \\
\hline G5 & Primary $6^{\text {th }}(12$ years old $)$ & 9 \\
\hline G6 & Secondary 1 st $(13$ years old $)$ & 28 \\
\hline $\begin{array}{l}\text { Total number of } \\
\text { participants }\end{array}$ & & 105 \\
\hline
\end{tabular}

Table 1. Groups data.

The methodology followed can be divided into different stages. The study started with an observation and audio recording period where the observer took note of any relevant sound and movement made by any class member during twelve FL classes. The following phase was destined to transcribe them and the corpus obtained was analyzed applying CODAM, a communicative discourse analysis model (Velasco, 2011) based on Sinclair and Coulthard's model, on Conversation Analysis findings (Tsui, 1994) and on Poyatos' tripartite conception of language (1994).

In this research, we have especially focused on studying learners' initiatives (Is) but it has also been necessary to analyze learners' responses (Rs) and follow up moves (Fs) as well as teachers' initiatives (I), responses (Rt) and follow up moves (F) in each class.

In addition, to get a more general view about learners initiations, we prepared a questionnaire and 90 Andalusian children ( 8 to 13) filled it in a non-formal learning setting (a summer camp in July 2013). They came from 30 different Andalusian schools (53\% of the total number of schools were public schools and $47 \%$ were private schools).

\section{Results}

Results are presented according to our preliminary questions:

a)Do learners' initiations occur in FL classes?

For this study we have only considered verbal initiatives although it is evident the existence of non-verbal initiations too. Here is an example of a verbal learner's initiation when the student speaks out of his turn, in order to ask about the meaning of which. It occurred when all students had to work individually on some written activities.

\begin{tabular}{|l|l|l|}
\hline Is & & S.-¿qué es which? \\
\hline Rt & $\begin{array}{l}\text { T.- Which cuando había que } \\
\text { elegir ¿eh? Es sinónimo de } \\
\text { what, lo único que cuando } \\
\text { hay que elegir ¿eh? Which? }\end{array}$ & \\
\hline Fs & & S.- which ¡ah! Which \\
\hline
\end{tabular}

Example 1 (author's database) 
In spite of having searched only for verbal acts produced by students in each group, we may find a considerable quantity of them in each group:

\begin{tabular}{|l|l|l|l|l|l|l|}
\hline & G1 & G2 & G3 & G4 & G5 & G6 \\
\hline $\begin{array}{l}\text { Total Learners Initiatives } \\
\text { (LIs) per group }\end{array}$ & 61 & 256 & 25 & 81 & 85 & 98 \\
\hline
\end{tabular}

Table 2. Learners' initiatives per group.

Table 2 clearly shows not only that students in all groups have made initiation turns, but also that there are great differences among groups, considering the number of verbal Initiation acts produced. The difference between G2 and G3 is very high, while G4 and G5 seemed to have a similar amount.

Quite surprisingly, we have checked that the quantity of learners' Initiations differs not only between groups but also between periods of class within the same group of students (Table 3). Thus, the difference between some sessions is very high (G2 or G6):

\begin{tabular}{|l|l|l|l|l|l|l|l|l|l|l|l|l|}
\hline & G1-1 & G1-2 & G2-1 & G2-2 & G3-1 & G3-2 & G4-1 & G4-2 & G5-1 & G5-2 & G6-1 & G6-2 \\
\hline Total LIs & 25 & 36 & 153 & 103 & 11 & 14 & 33 & 48 & 55 & 30 & 66 & 32 \\
\hline
\end{tabular}

Table 3. Learner's initiatives per sessions.

According to the above data, the media is situated on 50.5 learner initiation acts per session, but only 1 period of class (G4-2) is near the media. We thought that age could be a relevant factor, taking into account that young students are more restless and talkative than older ones, but we have also noticed that, although some young groups have made a lot of initiations, there is a young group which does not make many of them.

Wondering whether the FL learning experience had any connection with the learners' initiative production, we observed that groups with three years FL learning experience (G4, G5) present certain similarities between sessions, but beginners (G2 and G3) or 1 year FL learning experience both G1 and G6 (4-years of English) throw very different figures in the data. In sum, we find it too difficult to establish any kind of connection between the learning experience and the quantity of Initiations that a group can make. Nevertheless, we can state that at all levels of acquisition learners produce spontaneous initiatives, quite unexpected for the teacher.

We have compared our findings with an interview carried out in 2013 to 90 Andalusian children studying English at 30 different schools. Most of the interviewed students (81\%) came from public schools, whereas the remaining $19 \%$ came from private or semi-private schools. They were asked if they could speak spontaneously in class, without asking for permission (either in English or in Spanish) and 100\% answered 'no'. But also, they were asked at the same time about their teachers' reactions when a student talked without permission, and this time their answers were really interesting for this study: most of them (45\%) agreed that the teacher became very upset, telling them to be quiet and pay attention; others said they were told to copy out 100 times 'I have to be quiet in class'. Finally, some 
teachers seemed to send the student out of the classroom for a while or did not allow that student to go out to the patio at break time. The fact that they all replied to this question with more than one answer, sometimes using the first person, make us clear that initiations, either in L2 or in L1, actually occur in all classes.

It seems then evident from our data that Spanish children initiate at different moments during the teaching-learning process, at teacher's turn or other students' turn, as Fagan (2012) suggests.

We agree with Garton (2012) on the existence of confirmation checks, clarification requests, information requests as well as hypothesis testing in learners' initiatives, but we pursue to know the underlying reasons that encourage young learners to speak in class.

b) Why do learners make initiations in the FL class?

In the analysis carried out on our linguistic corpus, we have looked for the initiative acts produced by learners. The first issue we could comment on is the variety of acts made by learners to initiate. We have identified twenty-one different types of initiative acts and they have been named according to the illocutionary force that has prompted each of them. We realize that students have made use of the same or very similar acts to those likely to be produced by the teacher.

Types of Unexpected Learner-Initiative Acts:

Is(repetition)
Is(translation)
Is(singing)
Is(informative:report)
Is(informative:expressive)
Is(greeting)
Is(marker)
Is(nomination)
Is(give excuse)
Is(elicit:action)
Is(elicit:confirmation)
Is(elicit:information)
Is(elicit:commitment)
Is(lecturing 1)
Is(lecturing 2)
Is(suggest)
Is(protest)
Is(??)

Some of them belong to the group of informatives: Is (informative:report) is normally used to tell something that has happened in class or something personal connected with what is being explained in class, or Is(informative:expressive) is uttered to communicate some feeling about something. 
In another group are those whose main purpose is to elicit something from the teacher, like Is (elicit:commitment) when the student would like to participate in the activity in course, as can be seen in example 1:

\begin{tabular}{|l|l|l|l|}
\hline Is & & 10.-S3.- ¡señorita! ¿puedo apuntar? & $\begin{array}{l}\text { Is(nom) } \\
\text { Is(elic:commit) }\end{array}$ \\
\hline
\end{tabular}

Example 1. (author's database).

Is(elic:information) is used for asking something unknown; Is(elicit:confirmation) for searching confirmation of something they are not too sure about; Is(elicit:action) when the learner demands more action. Is(suggest) is used to make a suggestion connected with learning. Sometimes learners protest (Is: protest) and on other occasions, a learner repeats spontaneously (Is(repetition); translates Is(translation) or sings Is(singing) without being asked to do so, while the teacher is expecting someone else's response.

At the beginning or at the end of class Is (greeting) occurs very frequently. To give an excuse, for not having done homework, for example, Is (give excuse) is used.

We are likely to find $I$ (marker) and Is(nomination) when starting a turn.

Sometimes, the student 'takes the floor' to explain a classmate how to do some activities Is(lecturing1) or some grammar point or vocabulary Is(lecturing 2). And finally, we have labelled $I s(?$ ?) to an act that can hardly be audible, frequently used to talk to a partner, rather than to address the teacher.

One of the best ways to understand childrens' behaviour is by asking them and for that reason we decided to insert the following question: Why do children speak in the Foreign Language class? in the questionnaire that 90 children filled in (July 2013). Some children referred to the need of individuals to speak, making clear that to wait till break time was too long, but they forgot what they wanted to talk about with their classmates. Being near a friend seemed to be a social need to talk to him/her. Other answers are related to not being respectful to the teacher while they considered children not well behaved when they spoke freely, hence interrupting the class. But we have found many answers referring to a lack of attention on students' side for two main reasons: (1) they do not want to learn and (2) they do not understand what is being taught. These two reasons have much in common with boredom as the main reason given by $50 \%$. According to children' opinion, learner initiations occur in class when learners get bored, as most of the times they already know the answers or the explanation demanded.

c. How can learners' initiatives affect classroom development?

In our analysis, we have observed that all learners' initiations have had an impact on classroom development. Contrary to what some researchers' state, we have checked that not only are relevant the initiatives that take the main floor in class, since none of them seem to pass unnoticed to the rest of class members, especially the teacher.

To explore how learners' initiatives have affected classroom development in our corpus we have examined class members' reactions through the analysis of illocutionary acts produced after learner-initiatives. We have noticed that three are their attitudes that occur in our data: (1) to ignore learners' initiations; (2) to stop them or (3) to continue them, answering 
or giving a 'follow up'. Students are affected by other learners' initiatives, being able to take option 1, 2 or 3 and depending on the students' reaction, secondly on the pedagogical moment of the class in which it occurs, and finally on teacher's experience. The teacher options are: first ignoring learner initiative, second stopping it, reprimanding its producer, or finally to produce a 'follow up'. It is especially teachers' reaction to learners' initiatives what helps to appear what we will refer to incises. Thus, an incise could be defined as the communicative discourse generated in class and produced as a consequence of a learner's verbal or non-verbal initiation.

The following example shows an incise produced by a student during another learner's turn. At the same time that S1 is answering to the teacher, S2 elicits confirmation to the teacher, she wants to know whether they have to write the sentences already translated in English or if she has to copy them out first in Spanish and then in English. The teacher chooses to answer the question and continue with her planned turn. So this incise is formed by only two turns, with one act each.

\begin{tabular}{|l|l|l|l|}
\hline I & T.- más fuerte, Guille & & $\begin{array}{l}\text { I(dir:inst) } \\
\text { I(nom) }\end{array}$ \\
\hline R & & S1.- been & I(give pseudoinf) \\
\hline Is & $\begin{array}{l}\text { S2.- ¿lo hace- } \\
\text { mos directamen- } \\
\text { te? }\end{array}$ & Is(elic:conf) \\
\hline Rt & $\begin{array}{l}\text { T.- Nosotros, sí sí, lo hacemos direc- } \\
\text { tamente. } \\
\text { Nosotros estábamos en casa. } \\
\text { We were at home ¿eh? En casa siem- } \\
\text { pre con la preposición "at" ¿eh? }\end{array}$ & & $\begin{array}{l}\text { Rt(give inf) } \\
\text { I(elic:translate) } \\
\text { I(inf:lecturing2) } \\
\text { I(elicl:agree) }\end{array}$ \\
\hline
\end{tabular}

Example 2-(author's data).

Example 2, although it is formed by two turns, it is a longer incise, as it contains eight communicative acts. After a complete teacher's initiation, a student's response and teacher's follow up (IRF) exchange between the teacher and S3, S4 takes the floor to explain something about S3's answer and the teacher not only acknowledges his contribution, but also reinforces it by repeating the explanation to the rest of the students and makes sure that everybody understands it.

\begin{tabular}{|l|l|l|l|}
\hline I & T.- Elías, tú, léelo & & $\begin{array}{l}\text { I(nom) } \\
\text { I(dir:inst) }\end{array}$ \\
\hline R & & $\begin{array}{l}\text { S3.- Elías book is as } \\
\text { interesting as Adriana } \\
\text { and María's book }\end{array}$ & R(reading) \\
\hline F & T.- vale & & F(ack) \\
\hline Is & & $\begin{array}{l}\text { S4.- el segundo book } \\
\text { se puede omitir }\end{array}$ & $\begin{array}{l}\text { Is(inf:lecturing } \\
\text { 2) }\end{array}$ \\
\hline
\end{tabular}




\begin{tabular}{|c|c|c|}
\hline $\mathrm{F} / \mathrm{I}$ & $\begin{array}{l}\text { T.- por lo que vimos el otro día } \\
\text { ¿eh? } \\
\text { ¡Mirad! Ha dicho JC que el } \\
\text { segundo book él lo ha omitido. } \\
\text { Se puede omitir porque ya ha } \\
\text { salido antes ¿eh? El libro de } \\
\text { Elías es tan interesante ... como } \\
\text {... el de ... er .. Adriana y María } \\
\text { ¿vale? } \\
\text { En este caso se puede omitir } \\
\text { pero el que no lo quiera omitir lo } \\
\text { pone como la frase en español lo } \\
\text { pone ... ¿de acuerdo? }\end{array}$ & $\begin{array}{l}\text { F(ack) } \\
\text { I(marker) } \\
\text { I(inf:report) } \\
\text { I(inf:lecturing 2) } \\
\text { I(elic:agree) } \\
\text { I(lecturing 1) } \\
\text { I(elic:agree) }\end{array}$ \\
\hline
\end{tabular}

Example 2. (Author's data).

The purpose of the incise in example 2 is to explain something already learnt about L2 to others. In our linguistic corpus we have found a great deal of incises and looking at it from learners' point of view, we have identified at least, twenty types of incises according to what the learner pretends to do in each one. Here we present a list of types of incises made by Young Spanish learners of English.

\begin{tabular}{|l|l|}
\hline & Type of incise \\
\hline 1 & To ask for content doubts \\
\hline 2 & To ask for form doubts \\
\hline 3 & To talk to other classmate/s \\
\hline 4 & To inform about his/her learning process \\
\hline 5 & To volunteer oneself to do something \\
\hline 6 & For curiosity \\
\hline 7 & To ask for permission \\
\hline 8 & To tell others what to do \\
\hline 9 & To anticipate oneself to teacher's explanation \\
\hline 10 & To show enthusiasm \\
\hline 11 & To tell a experience \\
\hline 12 & To greet someone \\
\hline 13 & To suggest doing something \\
\hline 14 & To correct a classmate \\
\hline 15 & To fulfill a personal necessity \\
\hline 16 & To give an excuse \\
\hline 17 & To help a partner \\
\hline
\end{tabular}




\begin{tabular}{|l|l|}
\hline 18 & To query about something \\
\hline 19 & To show oneself is the naughty one \\
\hline 20 & To explain something about L2 language or culture \\
\hline
\end{tabular}

We have detected 326 cases of incises in total and the percentage of occurrence is unequal in the groups. The most common type in our data is number 3 , To talk to other classmate/s $(20,9 \%)$; the second place is 4 , To inform about his/her learning process (20,6\%); type 2, Doubts about Form, is in third position (15,6\%); type 1, Doubts about content $(8,6 \%)$, in 5 th position is $7,4 \%$ is type 13 , To suggest doing something, followed by type 5 , To volunteer oneself to do something $(5,2 \%)$.

The rest of the groups show a very low, therefore insignificant, percentage of occurrences.

Taking into account that the percentage obtained with the first five types of incises with higher frequency is above $73 \%$ of the total number of incises in our data, we decided to focus on them. In the following graphics it is shown the evolution of them in the different groups. The highest frequent type occurs when two or more students speak to each other off their speaking turn.

On Graphic 1 we may think that the first four groups ( 8 years old and under) have similar behaviour between $15 \%$ and $25 \%$ but it descends near $0 \%$ in group 5 , the opposite of G6 with the highest level, spending most of the class time speaking to others out of their speaking turn.

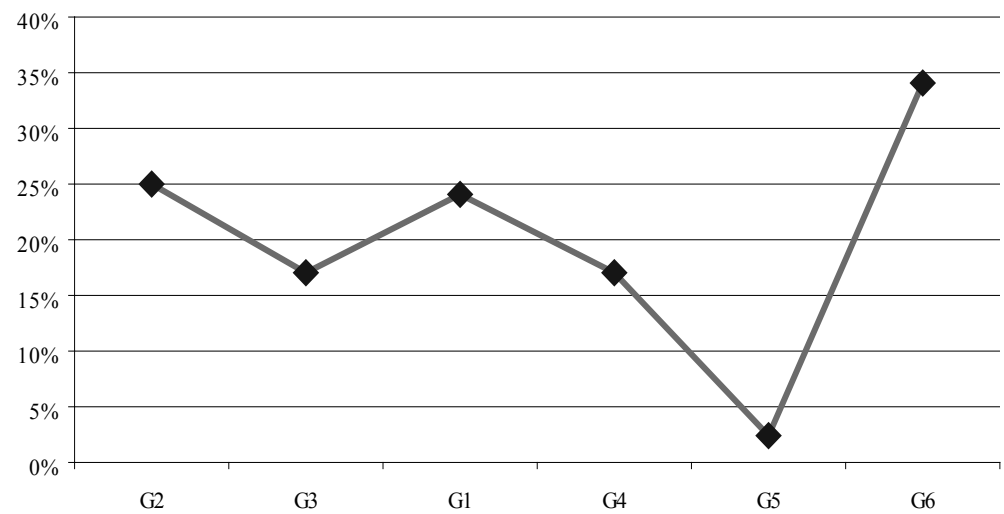

Graphic 1. Evolution of incises type: To talk to other classmates.

The difference among groups is so high that we cannot establish a connection between learners' age or the number of years they have been studying L 2 and the quantity of incises of this type found. For example, G5 and G6 results are completely different, in spite of sharing similar ages, only one year of difference.

Graphic 2, presenting data related to type 4 , shows a high percentage in the youngest students ( 5 and 6 years old) and a high decrease in the following groups that seem to 
correspond to their age. It seems apparent that the older the learners are, the less they inform about their learning process. We wonder whether the interest in informing shown in previous years, tend to disappear slightly or whether such behaviour has been acquired as a consequence of the teacher's attitude towards them.

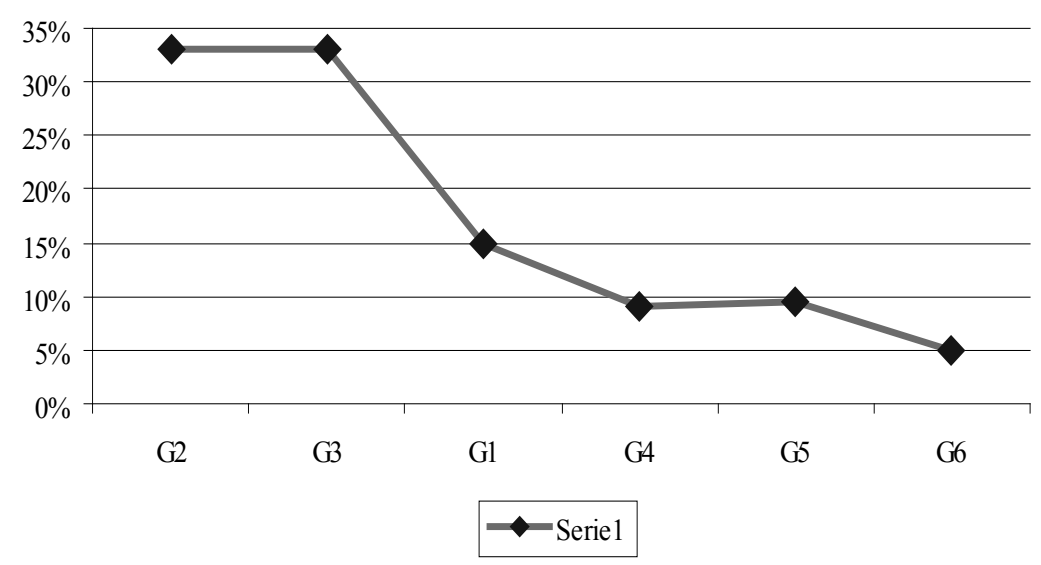

Graphic 2. Evolution of incises type 4 To inform about his/her learning process.

Here is an example of type 4: To inform about his/her learning level, which is set in a context where students are doing listening activities in groups. As soon as the teacher (T) informs the activity is about to start, $\mathrm{S} 3$ requests her to wait because he has not finished copying out the sentence, a task he should have done before, and T responds, however, in a positive way. Immediately after that, another student (S7) initiates with another informative report act to let the teacher know that she had already finished doing the requested action and she is ready to start. It is rather frequent to find several students' initiations of this kind, especially after the first student had been attended to by the teacher.

\begin{tabular}{|l|l|l|l|}
\hline I & 9.-T.- ¡Venga! ¡empezamos! & & $\begin{array}{l}\text { I(marker) } \\
\text { I(dir:inst) }\end{array}$ \\
\hline Is & & $\begin{array}{l}\text { 10.-S3.-Un mo- } \\
\text { mento, que termine } \\
\text { de copiar }\end{array}$ & $\begin{array}{l}\text { Is(req for ac- } \\
\text { tion) } \\
\text { Is(inf:report) }\end{array}$ \\
\hline NVRt & $\begin{array}{l}\text { 11.-(T stops and wait till S3 has } \\
\text { finished to copy) }\end{array}$ & $\begin{array}{l}\text { NVRt(positive } \\
\text { action) }\end{array}$ \\
\hline Is & & 12.-S7.-Yo ya & Is(inf:report) \\
\hline I & 13.-T.-Group A, pay attention! & & $\begin{array}{l}\text { I(nom) } \\
\text { I(dir:inst) }\end{array}$ \\
\hline
\end{tabular}

Example 1. (author's data). 
The evolution of incises type 2 Doubts about Form, in third position (15,6\%) and type 1 , To ask Content Doubts $(8,6 \%)$, is shown in the next graphic. One can observe great differences with respect to graphic 2, as students' behaviour seems to be quite regular, showing a tendency to increase the number of both types of incises as the factor age increases, except for the last group, where there are many incises type 2 and very few of type 1 and $\mathrm{G} 1$, with no incises of those types.

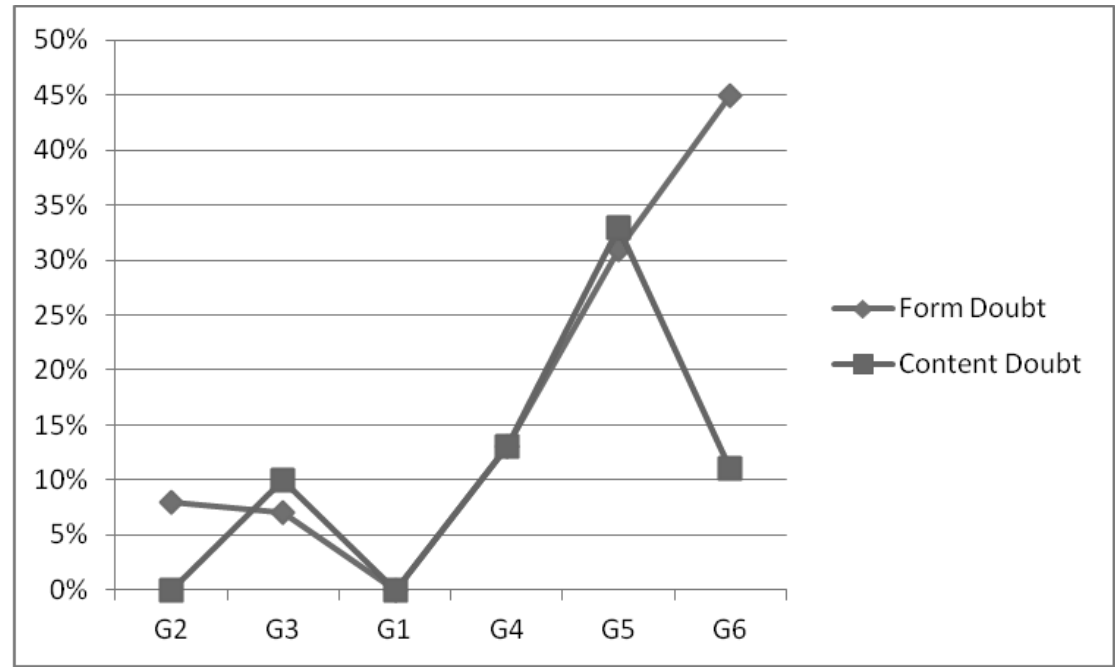

Graphic 3. Content and Form Doubts.

Example 3 is made by a five-year-old boy who is provoking an incise type 1, while asking for a content doubt.

\begin{tabular}{|l|l|}
\hline $\begin{array}{l}\text { T-¿Os gustan las Christmas bells? Una es jingle bell y éstas } \\
\text { son Christmas bells }\end{array}$ & \\
\hline & S1.-¿Esta es jingle bell? \\
\hline $\begin{array}{l}\text { T.-No, ésta es Christmas tree. Jingle bells son éstas, cielito } \\
\text { (las coge y canta mientras suena) } \\
\text { Jingle bells, jingle bells y estas son Christmas bells }\end{array}$ & \\
\hline
\end{tabular}

Example. (author's database).

A type 2 incise can be seen in example 4, where the student though he understands what he has to do, he does not know how to do it. It is a form doubt because, in this particular case, the student knows that he has been asked to sit down but he does not know where exactly he has to do it. In some other cases, the question is how. 


\begin{tabular}{|c|c|c|}
\hline $\mathrm{I}$ & $\begin{array}{l}\text { 3.-T.- ¡A ver! } \\
\text { S6, sit down. S7, sit down here (señala el suelo). } \\
\text { Sit down, sit down, sit down on the floor. }\end{array}$ & \\
\hline Is & & 4.-S6.- ¿dónde? \\
\hline $\mathrm{Rt}$ & 5.-T.- On tle floor. Sit down on the floor & \\
\hline & - dance & $\begin{array}{l}\text { 6.-(S6 sits down on the } \\
\text { floor) }\end{array}$ \\
\hline $\mathrm{F}$ & 7.- T.-Muy bien,... & \\
\hline
\end{tabular}

Example 4. (antherartiata).

- day

In this type of incise, the student usually makes an elicit:information or pseudoinformation act because it is searching for an I (lecturing 1) act from a teacher that, in many cases, $\mathrm{T}$ had previously produced. Finally, the fifth position is occupied by type 13 , To suggest doing something $(7,4 \%)$ :

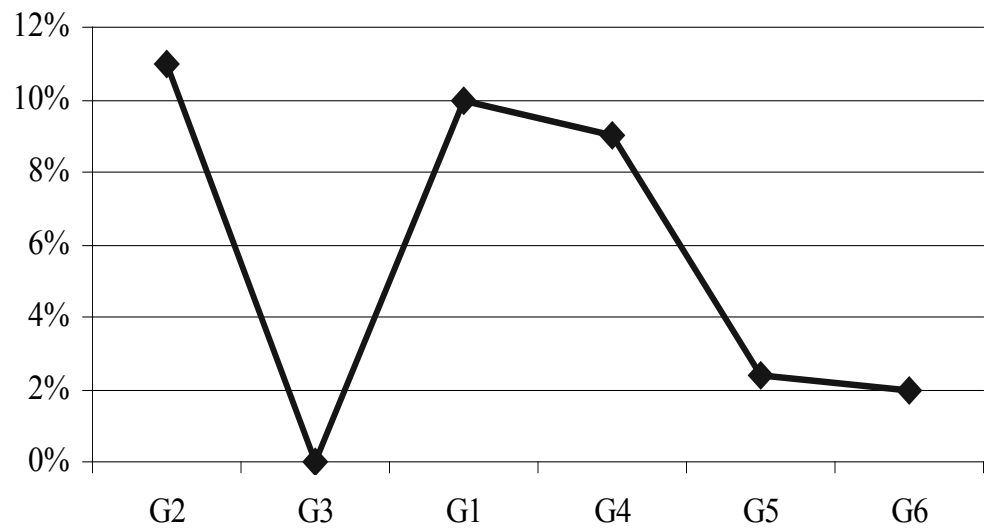

Graphic 4. Incises type 13. To suggest doing something.

As can be seen, the percentage of incises type 13 has been always inferior to $12 \%$, being very low in three groups, and it does not even appear at all in one group.

Undoubtedly, several differences have been found in groups and in types. Some groups have made a lot of incises of one type and not many of another one. We wonder if we should consider another factor, the teacher's tolerance to occurring incises, but then, what makes a teacher accept or reject incises? We believe that this is the key question, and as a consequence we have examined the length of incises, according to the quantity of turns and acts used. We have observed that the teachers' reaction to different incises are caused by a number of different factors. The longest of them correspond to incises of type 'content doubts'. On the other hand, 'form doubts' were not noticeably long, as teachers have replied to them quickly or even not attended to them at all. Some suggestions had been considered by the teachers, 
but most of them had not. Type 4 had been very short too and in those cases where learners have talked to each other without the teacher's permission, has sometimes caused a long incise, although teachers intention has always been to stop it as soon as possible, mainly because most of the time the incise has been expressed in the mother tongue.

The ones most attended to had been first, those expressed in English, and second, those trying to solve doubts about L2 or English culture. Probably because the teachers believe that such types of incises are those which bring the greatest L2 learning opportunities.

\section{CONCLUSIONS}

Some data gathered in this research indicate that every FL class contains learners' initiations as learners break in and speak out of their speaking turn.

First of all, we conclude that it is really profitable to explore such initiations. One of the best ways, in our opinion, is by applying a model based on a "communicative discourse analysis" to let us know the illocutionary acts used by learners to initiate in the FL class.

Our second finding is that younger students have a great variety of reasons to speak out of turn where we can detect up to eighteen different types of initiative acts.

Thirdly, we can state that students' out of turn initiations have an impact in the teachinglearning context. As a consequence, different types of incises come up from of students' initiating turns.

Another relevant conclusion is that there is a varied but limited number of types of incises. Twenty types of incises have been detected in our data, although only five (73\%) were the most frequent. Learners speak out of turn to communicate with other classmates for a number of reasons: to inform about their learning process; to ask doubts related to Form (how to do activities) or Content (about grammar, vocabulary, anything related to L2); and to suggest doing something.

On the other hand, and depending on the treatment received by the teacher and the rest of class members, the length of incises vary a lot. Teachers do not always react in the same way. They do not always cope with them. Apparently, teachers' tolerance depends on the relevance that each initiative has, according to the teacher's criterion, and it also depends on the particular moment when it occurs.

Although they are not the most frequent ones, incises asking doubts about the target language (type 1) are those teachers prefer to attend to, probably because they show students' interest about a specific grammar point, vocabulary, or any aspect related to L2. All learners' questions made in L2 have been answered by the teacher. It seems clear that incises creating more opportunities for learning are those expressed in L2 or showing students' interest for learning specific aspects of L2. In short, motivation is the most powerful engine for learning. On the contrary, incises that interrupt the normal course of the class in L1 or deviate to a different issue lead teachers to end them as soon as possible, as they are thought dangerous for the fluid development of the class, instead of a learning opportunity. Many teachers, especially novel teachers, associate learners' initiatives with discipline problems, what makes them to stop any kind of initiation coming from students.

In our opinion, it would be very positive if teachers in general, and future teachers in particular, could understand the benefit that learners' initiatives can bring to the FL class. 
Teachers should be trained in four main aspects: (1) how to treat learners' initiatives when they occur in class; (2) how to teach students to initiate, since they are mainly taught to respond; (3) to distinguish the learning moments when the different types of incises usually take place and (4) to create the appropriate atmosphere to encourage learner-initiatives.

In further work we shall focus on researching on the specific moments in class where specific types of learners' initiatives take place. This should enable us to predict ideal teaching situations to encourage ideal learners' initiation turns to take place in class.

\section{REFERENCES}

Allwright, D. 1983. "Classroom -centered research on language teaching and Learning: a brief historical overview”. TESOL Quarterly, 17,2: 191-204.

---..2005. "From teaching points to learning opportunities and beyond". TESOL Quarterly, 39, 1: 9-32.

BaILey, K.M. 1996. Voices from the Language Classroom. Cambridge: Cambridge University Press

FAGAN, D. S. 2012. "Dealing with' unexpected learner contributions in whole group activities: an examination of novice language teacher discursive practices". Classroom Discourse 3, 2: 107-128.

GARTON, S. 2012. "Speaking out of turn? Taking the initiative in teacher-fronted classroom interaction", Classroom Discourse, 3:1: 29-45.

Goodwin, M. H. 2007. "Occasioned knowledge exploration in family interaction". Discourse and Society 18, 1: 93-110.

JACKNIK, C. 2009. A conversation-analytic account of learner-initiated participation in an ESL classroom. Dissertation Abstract International 70/7. (UMI No.AAT 3368413) Retrieved February, 24, 2010.

---..2011. "Breaking in is hard to do. How students negotiate classroom activity shifts". Classroom Discourse 2:2-38.

Johnson, K. 1995. Understanding Communication in Second Language Classrooms. Cambridge: Cambridge University Press.

Poyatos, F. 1994. La comunicación no verbal. Madrid: Itsmo.

Richards, K. AND Seedhouse, P. 2005. Applying Conversation Analysis. London: Palgrave Macmillan.

SinClaIR, J. M. AND COUlthard, M. 1975. Towards an analysis of discourse. Oxford: Oxford University Press.

Tsui, A. B.M. 1994. English Conversation. Oxford: Oxford University Press.

VAN LIER, L. 2008. “Agency in the classroom”. LANTOLF, J and M. POCHNER. (EDS). Sociocultural theory and the teaching of second languages. London: Equinox. 163-86 
VelasCo, M.I. 2012. "Investigating participation level in Foreign Language Classrooms through the analysis of Communicative Discourse". Porta Linguarum, 17: 47-67

WARING, H. Z. 2009. "Moving out of IRF (Initiation- Response- Feedback): A single case analysis". Language Learning 59:796-824.

WaLSH, S. 2006. Investigating Classroom Discourse. New York: Routledge

---. . 2011. Exploring Classroom Discourse Language in Action. New York: Routledge. 